\title{
The distribution and metabolism of $\alpha$-tocopherol in the rat
}

\author{
By A. MELLORS* AND M. McC. BARNES \\ Biochemistry Department, University of Liverpool \\ (Received Io August 1965-Accepted in October 1965)
}

\begin{abstract}
1. A comparison of the distribution of radioactivity in rat tissue lipids after oral administration of $\left[5-M e-{ }^{14} \mathrm{C}\right]-\alpha$-tocopherol showed that spleen and adrenal lipids have a relatively high uptake of radioactivity. 2. Absorbed $\alpha$-tocopherol and its metabolites appeared not to re-enter the lumen of the gut in significant amount through the bile or by the secretion from the stomach mucosal cells within the $24 \mathrm{~h}$ experimental period. 3 . After ingestion of $\left[5-M e-{ }^{14} \mathrm{C}\right]-\alpha$-tocopherol by rats, analyses of their liver and spleen lipids showed that most of the radioactivity in the lipids was due to the presence of unchanged $\alpha$-tocopherol. Radioactive tocopherolquinone was found in both spleen and liver lipids; in the liver lipids there was some evidence that a second oxidation product of $\alpha$-tocopherol, compound $O$, had been formed.
\end{abstract}

There is conflicting evidence about the existence in the animal body of $\alpha$-tocopherol metabolites. Simon, Gross \& Milhorat (1956) reported finding a metabolite of $\alpha$ tocopherol, later called tocopheronic acid, and its lactone in the urine of rabbits given $\left[5-M e-{ }^{14} \mathrm{C}\right]-\mathrm{D}-\alpha$-tocopherol succinate by intravenous or subcutaneous injection. Simon, Eisengart, Sundheim \& Milhorat (1956) isolated these compounds from the urine of human subjects given $3-5 \mathrm{~g} \mathrm{D}-\alpha$-tocopherol daily and identified them as 2-(3-hydroxy-3-methyl-5-carboxyl-pentyl)-3,5,6-trimethyl-1,4-benzoquinone (I) and<smiles>CC1=C(C)C(=O)C(CCC(C)(O)CCC(=O)O)=C(C)C1=O</smiles>

I<smiles>CC(C)=CCC1=C(C)C(=O)C(C)=C(C)C1=O</smiles>

II

its $\gamma$-lactone. It was at one time suggested that tocopheronic acid was the active form of vitamin E or closely allied to it (Green, Edwin, Diplock \& Bunyan, I96I; Green, Diplock, Bunyan, Edwin \& McHale, 196r) but so far it has only been found as a urinary metabolite.

* Present address: Department of Food Science and Technology, University of California, Davis, California, USA. 
Martius \& Fürer (1963) identified a metabolite of $\alpha$-tocopherol, found in the tissues of rat, chick and earthworm, as 2,5,6-trimethyl-3-(farnesylfarnesylgeranylgeranyl)-r,4benzoquinone (II) referred to as $E_{2(50)}$ by analogy with the vitamins $\mathrm{K}$ and suggested that it was the metabolite of $\alpha$-tocopherol responsible for specific vitamin E activity as apart from non-specific antioxidant activity. It is perhaps significant that tocopheronic acid is an intermediate in the proposed scheme for the interconversion of $\alpha$-tocopherol to $E_{2(50)}$.

Two oxidation products of $\alpha$-tocopherol have been reported in animal tissues. The first of these, tocopherolquinone, has been reported by several authors. Morton \& Phillips (1959) found tocopherolquinone in rat liver and trace amounts in rat kidney and rat heart. Draper, Csallany \& Shah (1962) and Plack \& Bieri (1964) found tocopherolquinone in the livers of rats, previously deficient in vitamin $\mathrm{E}$, given $\left[5-\mathrm{Me}^{-14} \mathrm{C}\right]-$ $\alpha$-tocopherol. Weber \& Wiss (1963) found $\alpha$-tocopherolquinone in the depot fats of rats, previously deficient in vitamin $\mathrm{E}$, but were unable to find any metabolites in the liver, or in the brain.

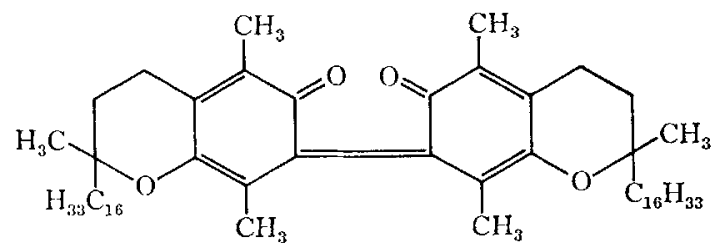

III

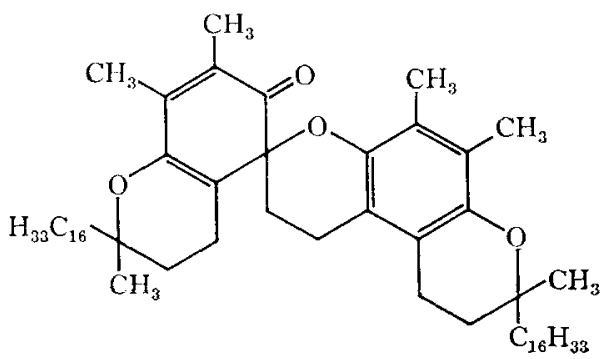

IV

Alaupović, Johnson, Crider, Bhagavan \& Johnson (196I) found three labelled compounds in the livers of rats and pigs given $\left[{ }^{14} \mathrm{C}\right]-\alpha$-tocopherol by intraperitoneal injection. Also Draper et al. (1962) isolated one of these metabolites, compound O, from the livers of rats previously made deficient in vitamin $\mathrm{E}$ and given $\left[5-\mathrm{Me}^{-14} \mathrm{C}\right]-$ $\alpha$-tocopherol, and showed it to be identical with a product prepared in vitro by oxidizing $\alpha$-tocopherol with potassium ferricyanide. Csallany \& Draper (1963) identified this as a dimeric oxidation product of $\alpha$-tocopherol to which they assigned the structure (III). But Nelan \& Robeson (1962) suggested that the main product of in vitro oxidation of $\alpha$-tocopherol with alkaline ferricyanide was a dimeric keto ether (IV); this structure was proved by Schudel, Mayer, Metzger, Rüegg and Isler ( 1963$)$. Skinner \& Alaupović ( $\left.196_{3}\right)$ investigated the products obtained when $\alpha$-toco- 
pherol was oxidized with alkaline ferricyanide and found that $65-75 \%$ of the total product was dimeric, as structure IV, but $2-3 \%$ was in the form of a trimeric oxidation product (V). Further evidence for this structure was provided by Skinner \& Parkhurst (1964) working with an analogue of $\alpha$-tocopherol. Skinner \& Alaupovic found that the ultraviolet absorption spectrum, infrared absorption spectrum and paper chromatogram of the trimeric product, rather than the dimeric product, resembled that of compound $\mathrm{O}$.

The aim of the study now presented was to trace the route of $\alpha$-tocopherol in rats free from any nutritional deficiency so that normal patterns of distribution and metabolism of the vitamin could be investigated.

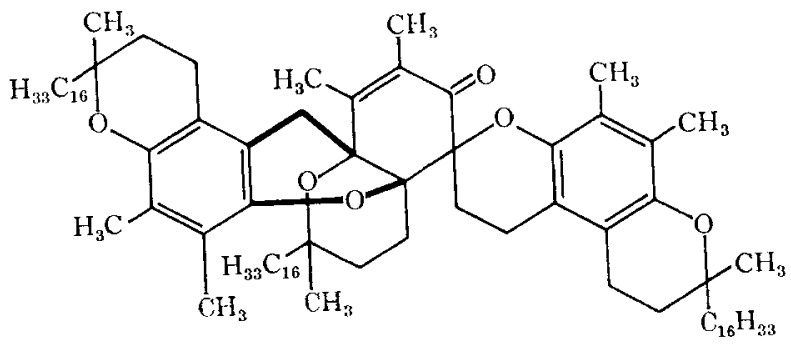

V

\section{EXPERIMENTAL}

Norwegian hooded rats from the stock colony kept in this department were used throughout. They were maintained on food cubes (No. 4 diet; British Extracting Co. Ltd, Bromborough Port, Cheshire). Diet and water were given ad lib.

Isotopically labelled $\alpha$-tocopherol was prepared from $\left[5-M e-{ }^{14} \mathrm{C}\right]-\alpha$-tocopherol succinate (Distillation Products Industries, Rochester, NY) by reduction with lithium aluminium hydride by the method of Duggan (1959), and its purity was established by chromatography on zinc carbonate-impregnated paper.

Twelve male rats, 4-6 months old, were each given by stomach tube $0.5 \mathrm{ml}$ of a solution of $\left[5^{-M e^{14}} \mathrm{C}\right]-\alpha$-tocopherol in arachis oil $(0 \cdot 36 \mu \mathrm{c} / \mathrm{ml})$. Groups of three rats were killed $3,6,12$ or $24 \mathrm{~h}$ after dosing. When the interval between dosing and killing exceeded $\mathrm{I} 2 \mathrm{~h}$ the animals were fitted with aluminium tail cups to prevent coprophagy. Before each animal was killed and while it was under anaesthesia its bile was collected for $\mathrm{I} h$ by means of a cannula inserted into the common bile duct.

Organs from the three rats killed at each time interval were dissected out and pooled. The collected tissues were the liver, kidneys, spleen, adrenals, testes, pelt, stomach, intestine (from the duodenum to the colon) and the caecum. The rest of the carcasses were pooled, minced finely in a hand mincer and mixed thoroughly; a large sample was taken for extraction.

The tissues were homogenized in $20 \mathrm{ml}$ chloroform-methanol $(2: \mathrm{r}, \mathrm{v} / \mathrm{v})$ per $\mathrm{g}$ tissue and lipids were extracted into chloroform by the technique of Albrink (1959-60). 
The radioactivity of a small measured portion of each chloroform extract was measured in a Packard Tri-Carb liquid scintillation counter. A minimum of 5000 counts $/ \mathrm{min}$ above the background was recorded for each sample.

Livers and spleens from ten male rats killed $24 \mathrm{~h}$ after being given $\left[5-\mathrm{Me}^{-14} \mathrm{C}\right]-\alpha-$ tocopherol orally were homogenized in isotonic sucrose at $0^{\circ}$, and cell particles were separated by centrifugation by the method of Schneider (1948). Lipids were extracted from each fraction (Folch, Lees \& Stanley, 1957), and the radioactivity of each fraction was determined as before.

To identify the radioactive material in the liver and spleen, forty-six female rats were given $0.36 \mu \mathrm{c}\left[5-M e-{ }^{14} \mathrm{C}\right]-\alpha$-tocopherol by stomach tube and were killed $24 \mathrm{~h}$ later. The livers and spleens were removed, and lipids were extracted into chloroform by the technique of Albrink (1959-60). These lipids were then separated by chromatography on acid-washed alumina (Brockman grade III) with mixtures of diethyl ether in light petroleum (b.p. $40-60^{\circ}$ ) of increasing polarity to elute the lipids. Radioactive fractions were subjected to further purification on Io $g$ columns of Decalso F (Permutit Co.) and finally separated by thin-layer chromatography and paper chromatography. Lipid was separated on thin layers of silica gel G (Merck) developed with $15 \%(\mathrm{v} / \mathrm{v})$ ethyl acetate in benzene. The paper-chromatographic separation was a modification of the method recommended for the analysis of tocopherols by the Society for Analytical Chemistry: Analytical Methods Committee (I959). Lipid dissolved in cyclo-hexane was spotted on $20 \mathrm{~cm}^{2}$ zinc carbonateimpregnated paper (Whatman no. $\mathrm{I}$ ) and developed in the first dimension by $\mathrm{I} \%$ $(\mathrm{v} / \mathrm{v})$ acetone in light petroleum. After impregnating with liquid paraffin, the chromatogram was developed in the second dimension with $95 \%(\mathrm{v} / \mathrm{v})$ aqueous ethanol.

\section{RESULTS}

\section{Distribution of radioactivity}

The distribution of radioactivity in rat tissues after oral administration of $[5-M e-$ $\left.{ }^{14} \mathrm{C}\right]$ - $\alpha$-tocopherol, expressed as counts/min $\mathrm{g}$ tissue, counts/min g extracted lipid and as a percentage of the dose, is shown in Table $\mathbf{x}$.

Most of the radioactivity found $3 \mathrm{~h}$ after the administration of the dose was in the stomach and intestine, presumably in the contents. These levels fell rapidly in the next $3 \mathrm{~h}$, whereas the radioactivity in the caecum increased from $2 \cdot 2 \%$ of the dose to $20.3 \%$. Presumably between 6 and $\mathrm{I} 2 \mathrm{~h}$ much of the radioactivity was voided with the faeces. After $24 \mathrm{~h}$ only about $20 \%$ of the administered radioactivity was recovered from the body.

No significant radioactivity was detected in bile samples collected in the hour before slaughter ('Table 2).

When the distribution of radioactivity in the tissues is expressed in the three ways listed above, it is seen that, although, the adrenal and the spleen, for example, take up most radioactivity relative to their weight and lipid content, because of their relatively low weights the fraction of the dose taken up by them is small. As might be expected, the liver takes up the largest percentage of the dose. Table 3 lists organs in descending 
order of uptake calculated in these three ways after $24 \mathrm{~h}$; stomach, intestine and caecum are not included.

Table 4 shows the intracellular distribution of the radioactivity found in rat liver and spleen. There was a clear difference in distribution. In the spleen $59.3 \%$ of the recovered ${ }^{14} \mathrm{C}$ was associated with the mitochondrial fraction, $18.8 \%$ with the microsomal fraction. In the liver, the microsomal fraction contained a bigger proportion of ${ }^{14} \mathrm{C}$ found, $43 \cdot 7 \%$ compared to $12 \cdot 2 \%$ in the mitochondrial fraction.

Table I. Distribution of radioactivity in rat tissues after oral administration of $0 \cdot 18 \mu c\left[5-\mathrm{Me}-{ }^{14} \mathrm{C}\right]-\alpha$-tocopherol $3,6,12$ and $24 h$ after dosing

Radioactivity

\begin{tabular}{|c|c|c|c|c|c|c|c|c|c|c|c|c|}
\hline \multirow[b]{3}{*}{ Tissue } & \\
\hline & \multicolumn{4}{|c|}{ Counts/min $\mathrm{g}$ tissue } & \multicolumn{4}{|c|}{ Counts/min g lipid } & \multicolumn{4}{|c|}{$\%$ of dose } \\
\hline & $3 \mathrm{~h}$ & $6 \mathrm{~h}$ & I $2 \mathrm{~h}$ & $24 \mathrm{~h}$ & $3 \mathrm{~h}$ & $6 \mathrm{~h}$ & $12 \mathrm{~h}$ & $24 \mathrm{~h}$ & $3 \mathrm{~h}$ & $6 \mathrm{~h}$ & $12 \mathrm{~h}$ & $24 \mathrm{~h}$ \\
\hline Liver & 260 & 885 & 482 & 8 Io & 6850 & 22200 & I6300 & 9580 & $\mathbf{x} \cdot 96$ & $4 \cdot 20$ & $2 \cdot 80$ & 3.74 \\
\hline Kidney & 37 & $44^{8}$ & 105 & 190 & 69 & 9170 & $443^{\circ}$ & 5120 & 0.05 & 0.39 & O. I I & 0.17 \\
\hline 'Stomach'* & 3100 & 2040 & 305 & 126 & 60000 & 36200 & 10900 & 2290 & 13.07 & 3.30 & $1 \cdot 05$ & 0.29 \\
\hline 'Intestine'* & 2920 & 963 & 467 & 346 & 17080 & 7060 & 2340 & I 600 & $16 \cdot 24$ & $3 \cdot 75$ & $2 \cdot 71$ & $\mathbf{I} 67$ \\
\hline 'Caecum'* & 405 & $5 \times 70$ & I 263 & $55 \mathrm{I}$ & 7720 & 95500 & $1445^{\circ}$ & 6390 & $2 \cdot 17$ & $20 \cdot 28$ & 5.43 & $2 \cdot 00$ \\
\hline Testis & 7 & I34 & 68 & $9 \mathrm{~T}$ & 299 & 3720 & 2520 & 2830 & 0.00 & 0.15 & 0.09 & 0.10 \\
\hline Spleen & $3^{87}$ & 986 & I I IO & 1271 & 13640 & 46200 & 27500 & 28700 & 0.09 & 0.25 & 0.25 & 0.19 \\
\hline Adrenal & 543 & I 510 & 5380 & I 675 & 4550 & 6970 & 38600 & 22280 & 0.01 & 0.03 & 0.11 & 0.03 \\
\hline Pelt & I IO & 85 & 103 & 166 & I 875 & 685 & 995 & 1920 & $2 \cdot 72$ & $I \cdot 58$ & $2 \cdot 50$ & 3.52 \\
\hline \multirow[t]{2}{*}{ Rest of carcass } & 392 & 93 & 216 & 148 & 3820 & I 569 & I 935 & 1225 & 30.40 & $7 \cdot 48$ & $15 \cdot 55$ & $8 \cdot 22$ \\
\hline & \multicolumn{8}{|c|}{ Total recovery } & $66 \cdot 7 I$ & $4 I \cdot 4 I$ & 30.60 & 19.93 \\
\hline
\end{tabular}

Table 2. Radioactivity found in individual samples of rat bile after oral administration of $0 \cdot{ }_{1} 8 \mu c\left[5-\mathrm{Me}-{ }^{14} \mathrm{C}\right]-\alpha$-tocopherol

Wt of bile collected during i $\mathrm{h}(\mathrm{g})$

Activity: (counts/min above background)

$\%$ dose

\begin{tabular}{cccc}
\multicolumn{4}{c}{ Time after dose } \\
$2-3 \mathrm{~h}$ & $5-6 \mathrm{~h}$ & II-12 h & $23-24 \mathrm{~h}$ \\
0.4238 & 0.5976 & 0.2177 & 0.6098 \\
& 0.5697 & 0.5160 & 0.3765 \\
28 & 64 & 22 & $1 \mathrm{I}$ \\
- & 101 & 12 & 25 \\
0.012 & 0.027 & 0.009 & 0.005 \\
- & 0.043 & 0.005 & 0.011
\end{tabular}

Table 3. Rat tissue listed in order of relative radioactivity content $24 h$ after the oral administration of $\left[5-\mathrm{Me}-{ }^{14} C\right]-\alpha$-tocopherol

\begin{tabular}{lrlrll}
\multicolumn{2}{c}{ Counts/min $\mathrm{g}$ tissue } & \multicolumn{2}{c}{ Counts/min g lipid } & \multicolumn{2}{c}{$\%$ of dose } \\
Adrenal & I 675 & Spleen & 28700 & Liver & 3.74 \\
Spleen & I 27I & Adrenal & 22280 & Spleen & 0.19 \\
Liver & 810 & Liver & 9580 & Kidney & 0.17 \\
Kidney & I90 & Kidney & 5120 & Testis & 0.10 \\
Testis & 91 & Testis & 2830 & Adrenal & 0.03
\end{tabular}


Table 4. Intracellular distribution of radioactivity in rat liver and spleen tissue $24 h$ after oral administration of $\left[5-\mathrm{Me}-{ }^{14} C\right]-\alpha$-tocopherol

\begin{tabular}{|c|c|c|c|c|c|}
\hline \multirow[b]{2}{*}{ Tissue } & \multicolumn{2}{|c|}{ Radioactivity } & \multirow[b]{2}{*}{ Tissue } & \multicolumn{2}{|c|}{ Radioactivity } \\
\hline & Counts/min & $\%$ total & & Counts $/ \mathrm{min}$ & $\%$ total \\
\hline Spleen: & & & iver : & & \\
\hline Nuclei & 1846 & $9 \cdot 6$ & Nuclei & $33^{\circ}$ & 13.5 \\
\hline Mitochondria & 11325 & $59 \cdot 3$ & Mitochondria & 300 & $12 \cdot 2$ \\
\hline Microsomes & 3601 & 18.8 & Microsomes & 1070 & 43.7 \\
\hline Supernatant fraction & 2334 & $12 \cdot 2$ & Supernatant fraction & 755 & 30.6 \\
\hline
\end{tabular}

\section{Liver analysis}

Eight livers were obtained from rats that had been given $\left[5-M e-{ }^{14} \mathrm{C}\right]-\alpha$-tocopherol $24 \mathrm{~h}$ before death, and the chloroform-soluble liver lipids were extracted. Of the radioactivity found in the chloroform extract $97 \%$ was soluble in acetone. The acetone-soluble lipid was chromatographed on acid-washed alumina and eluted with mixtures of diethyl ether in light petroleum of increasing polarity. The bulk $(86.7 \%)$ of the recovered radioactivity was eluted in the $2 \%$ and $4 \%(\mathrm{v} / \mathrm{v})$ diethyl ether in light petroleum fractions (fractions 2 and 3 respectively). Of the other fractions, the $15 \%$ $(\mathrm{v} / \mathrm{v})$ diethyl ether in light petroleum fraction (fraction 6) contained the most radioactivity $(4.3 \%)$. Interfering substances were removed from these three fractions by further purification on Io $\mathrm{g}$ columns of Decalso $\mathrm{F}$ to remove vitamin $\mathrm{A}$ and sterols. Thin-layer chromatography then showed that the bulk of the radioactive material in fractions 2 and 3 was $\alpha$-tocopherol $\left(R_{f} 0.75\right)$ and that the radioactive material in fraction 6 was $\alpha$-tocopherolquinone $\left(R_{f} 0^{\circ} 43\right)$. This was confirmed by the ultraviolet absorption spectrums of these fractions. Paper chromatography of fractions 2 and 3 revealed two radioactive components: one was $\alpha$-tocopherol and accounted for $71 \%$ and $62 \%$ of the recovered radioactivity in these fractions; the other component corresponded in chromatographic behaviour to compounds found by Alaupović et al. (1961) and by Draper et al. (1962) and accounted for $12 \%$ and $15 \%$ of the radioactivity in the purified fractions 2 and 3 , respectively. The latter compound was observed on paper chromatograms with an $R_{f}$ close to 1.00 in the system I \% (v/v) acetone in light petroleum and an $R_{f}$ close to zero in the reversed phase system developed with $95 \%(\mathrm{v} / \mathrm{v})$ aqueous ethanol.

\section{Spleen analysis}

Table I shows that the lipids of the spleen became relatively highly labelled, as assessed by counts/min $\mathrm{g}$ lipid, after rats were fed with $\left[5-M e-{ }^{14} \mathrm{C}\right]-\alpha$-tocopherol. To establish the nature of the radioactive material, spleens were obtained from forty-six female rats killed $24 \mathrm{~h}$ after the administration by stomach tube of $\left[5-M e-{ }^{14} \mathrm{C}\right]-\alpha-$ tocopherol, and the chloroform-soluble lipids were extracted by the technique used to extract liver lipids. The pooled extracts were subdivided into an acetone-soluble fraction, containing $91 \%$ of the total lipid radioactivity, and an acetone-insoluble fraction, which was discarded. The acetone-soluble lipid was chromatographed on 
acid-washed alumina, and radioactive fractions were purified on $10 \mathrm{~g}$ columns of Decalso $\mathrm{F}$ and by chromatography on thin layers of silica gel and zinc carbonateimpregnated papers, as described previously. Of the total radioactivity recovered from the alumina column, the bulk $(74 \%)$ was in the fraction eluted by $4 \%(\mathrm{v} / \mathrm{v})$ of diethyl ether in light petroleum. When measured portions of this fraction were chromatographed on thin layers of silica gel and on zinc carbonate-impregnated papers, only one radioactive compound was found. This was shown to be $\alpha$-tocopherol by its ultraviolet absorption spectrum and by its chromatographic behaviour. The fraction eluted from alumina column by $15 \%(\mathrm{v} / \mathrm{v})$ diethyl ether in light petroleum contained $12 \%$ of the recovered radioactivity, and this fraction clearly showed the ultraviolet absorption spectrum of $\alpha$-tocopherolquinone; when chromatographed on thin layers of silica gel developed with $15 \%(\mathrm{v} / \mathrm{v})$ of ethyl acetate in benzene, this radioactive material had the same $R_{f}(0.57)$ as pure synthetic $\alpha$-tocopherolquinone.

\section{DISCUSSION}

The pattern of distribution of radioactivity in the tissues of rats given $\left[5-M e-{ }^{14} \mathrm{C}\right]-$ $\alpha$-tocopherol orally was like that found by Wiss, Bunnell \& Gloor (r962), who used $\left[8-M e-{ }^{14} \mathrm{C}\right]-\alpha$-tocopheryl acetate in similar experiments. Thus spleen and adrenal tissue lipids reached the highest levels of radioactivity, with liver and kidney lipids also reaching relatively high levels. However, testis lipids, from an organ with a known requirement for vitamin $\mathrm{E}$, were relatively low in radioactivity. Scharpenseel (1959) has shown that the high uptakes of radioactivity found in the adrenal and spleen are not specific to vitamin $E$ or its metabolites. He gave tritiated vitamin A acetate to vitamin A-deficient rats and showed the highest uptake of radioactivity to be in the spleen, adrenals and gonads. Little is known about the role of the adrenals and the reticulo-endothelial system, especially the spleen, in lipid metabolism. In common with other parts of the reticulo-endothelial system, such as the Kupffer cells of the liver, the spleen has the capacity to remove lipids from the blood, which may explain the relatively high uptake of fat-soluble vitamins by the spleen.

Sternberg \& Pascoe-Dawson (1959) found a second maximum of radioactivity in the stomach of rats $24 \mathrm{~h}$ after oral administration of $\left[5-M e-{ }^{14} \mathrm{C}\right]-\alpha$-tocopheryl succinate. They attributed this phenomenon to the secretion of radioactive tocopherol or some metabolite into the lumen of the gut. Krishnamurthy \& Bieri (1963) also reported a second increase in the radioactivity of the rat stomach and its contents after the ingestion of radioactive $\alpha$-tocopherol. In both studies the second increase occurred $16-24 \mathrm{~h}$ after feeding, which suggests that it may have been caused by coprophagy. Sternberg \& Pascoe-Dawson (1959) do not record that they prevented coprophagy. Krishnamurthy $\&$ Bieri used tail cups in some experiments, but it is not clear that the animals in which the second peak in ${ }^{14} \mathrm{C}$ activity was observed were so fitted. In our study, tail cups were fitted to rats kept alive longer than $12 \mathrm{~h}$ after the ingestion of a radioactive dose, and no second maximum was observed (Table 1 ).

Simon, Gross \& Milhorat (1956) showed that tocopherol or some metabolite is secreted into the gut. They found $50-60 \%$ of the total radioactivity of an intra- 
venous dose of $\left[{ }^{14} \mathrm{C}\right]-\alpha$-tocopheryl succinate in the faeces of rabbits, previously deficient in vitamin $\mathrm{E}$, over a period of 20 days. The maximum excretion occurred on the $4^{\text {th }}$ day, when $7 \%$ of the administered radioactivity was found. Klatskin \& Molander (1952) and Johnson (1956) suggested that the bile is a route for the excretion of $\alpha$-tocopherol. Bile collected for I h before slaughter 3,6 , I2 and $24 \mathrm{~h}$ after oral administration of $\left[{ }^{14} \mathrm{C}\right]-\alpha$-tocopherol contained only insignificant amounts of ${ }^{14} \mathrm{C}$ (Table 2). Schmandke \& Proll (1964) found $2.4 \%$ of an intravenous injection of $5 \mathrm{mg}$ $\alpha$-tocopherol in the bile of rats in the subsequent $96 \mathrm{~h}$; approximately $0.7 \%$ of the dose was found in the first $24 \mathrm{~h}$. The larger dose, as well as the more direct route of administration, intravenous injection, led to greater excretion of tocopherol in the bile, as might be expected, but again these amounts were insufficient to explain the levels of tocopherol which have been found in the faeces.

In the liver and spleen cells the radioactivity from orally administered $\left[5-\mathrm{Me}^{-14} \mathrm{C}\right]-$ $\alpha$-tocopherol was associated mainly with the structural components. In the spleen most of the radioactivity found was associated with the mitochondria $(60 \%)$, but in the liver a greater proportion of the recovered radioactivity was found in the microsomal fraction $(44 \%)$ (Table 3$)$.

No evidence was found for the presence in rat tissues of tocopheronic acid or its $\gamma$-lactone, found in the urine of rabbits and human subjects by Simon, Gross \& Milhorat (1956) and Simon, Elsengart, Sundheim \& Milhorat (1956). Nor was there any indication that $\alpha$-tocopherol gave rise to a quinone, 2 (farnesylfarnesylgeranylgeranyl)-3,5,6 trimethyl benzoquinone, $\mathrm{E}_{\mathrm{g}(50)}$, reported by Martius \& Fürer (1963) to be a metabolite of $\alpha$-tocopherol in the rat, chicken and earthworm. In our study, after administration of ${ }^{14} \mathrm{C}$-labelled $\alpha$-tocopherol to adequately fed rats and subsequent analysis of their spleen and liver lipids, it became clear that the bulk of the radioactivity within these lipids was in the form of $\alpha$-tocopherol. After alumina chromatography of the spleen lipids, the bulk of the recovered radioactivity $(55 \%)$ was shown to be $\alpha$-tocopherol and I $2 \%$ was shown to be $\alpha$-tocopherolquinone. When the liver lipids were chromatographed on alumina, $87 \%$ of the recovered radioactivity was found in two adjacent fractions. Analyses of these two fractions showed that $60-70 \%$ of the recovered radioactive material in these fractions was $\alpha$-tocopherol and that $12-15 \%$ of the radioactivity was associated with a compound having the chromatographic properties of the compound $\mathrm{O}$ found by Alaupović et al. (I96r). Another fraction of the rat liver lipid contained $4 \%$ of the total recovered radioactivity and was shown to contain ${ }^{14} \mathrm{C}$-labelled $\alpha$-tocopherolquinone.

These results suggest that, in the livers of adequately fed rats, the formation of $\alpha$-tocopherolquinone and compound $O$ from $\alpha$-tocopherol is not as extensive as in vitamin E-deficient livers (Draper et al. 1962). Our study supports the earlier evidence that $\alpha$-tocopherolquinone and 'compound O' are normal metabolites of $\alpha$-tocopherol in the rat, although the compounds can also arise as artifacts under certain conditions. These experiments, on rats not subjected to any nutritional deficiency, show that the greater part of $\alpha$-tocopherol absorbed appears to remain intact in the tissues for some time. 


\section{REFERENCES}

Alaupović, P., Johnson, B. C., Crider, Q., Bhagavan, H. N. \& Johnson, B. J. (196r). Am. J. clin. Nutr. 9, no. 4, part 2, p. 76 .

Albrink, M. J. (1959-60). F. Lipid Res. I, 53.

Csallany, A. S. \& Draper, H. H. (1963). 7 . biol. Chem. 238, 29 r 2.

Draper, H. H., Csallany, A. S. \& Shah, S. N. (1962). Biochim. biophys. Acta, 59, 527.

Duggan, D. E. (1959). Arch. Biochem. Biophys. 84, I 16.

Folch, J., Lees, M. \& Stanley, G. H. S. (1957). F. biol. Chem. 226, 497.

Green, J., Diplock, A. T., Bunyan, J., Edwin, E. E. \& McHale, D. (196r). Nature, Lond., r9o, 318.

Green, J., Edwin, E. E., Diplock, A. T. \& Bunyan, J. (196r). Biochim. biophys. Acta, 49, 417.

Johnson, B. C. (1956). In Vitamina E. Atti del Terzo Congresso Internationale, Venezia, 1955, p. 125. Verona: Edizioni Valdonega.

Klatskin, G. \& Molander, D. W. (1952). F. clin. Invest. 31, I 59.

Krishnamurthy, S. \& Bieri, J. G. (1963). F. Lipid Res. 4, 330.

Martius, C. \& Fürer, E. (1963). Biochem. Z. 336, 474 .

Morton, R. A. \& Phillips, W. E. J. (1959). Biochem. 7. 73, 427.

Nelan, D. R. \& Robeson, C. D. (1962). F. Am. chem. Soc. 84, 2963.

Plack, P. A. \& Bieri, J. G. (1964). Biochim. biophys. Acta, 84, 729.

Scharpenseel, H. W. (1959). Landw. Forsch. 12, 120.

Schmandke, H. \& Proll, J. (1964). Int. Z. VitamForsch. 34, 312.

Schneider, W. C. (1948). F. biol. Chem. 176, 259.

Schudel, P., Mayer, H., Metzger, J., Rüegg, R. \& Isler, O. (1963). Helv. chim. Acta, 46, 636.

Simon, E. J., Eisengart, A., Sundheim, L. \& Milhorat, A. T. (1956). Y. biol. Chem. $221,807$.

Simon, E. J., Gross, C. S. \& Milhorat, A. T. (1956). F. biol. Chem. 221, 797.

Skinner, W. A. \& Alaupović, P. (1963). Science, N. Y., r4o, 803.

Skinner, W. A. \& Parkhurst, R. M. (1964). F. org. Chem. 29, 3601.

Society for Analytical Chemistry: Analytical Methods Committee (1959). Analyst, Lond., 84, 356.

Sternberg, J. \& Pascoe-Dawson, E. (1959). Can. med. Ass. F. 80, 266.

Weber, F. \& Wiss, O. (1963). Helv. physiol. pharmac. Acta, 21, I 31 .

Wiss, O., Bunnell, R. H. \& Gloor, U. (1 962). Vitams Horm. 20, 441. 